\title{
Pengaruh Faktor-Faktor Fundamental Terhadap Harga Saham Pada Perusahaan Asuransi Di BEI 2009-2012
}

\author{
Robert Lambey \\ (Email : robert_lambey@yahoo.com)
}

\begin{abstract}
The purpose of this study to know the influence of fundamental factors that ROA, $D E R, T A T O$, and CR on stock price. In this case the researchers used data in the form of financial statements food and beverage companies listed in Indonesia Stock Exchange (IDX). Researchers used a population of 10 companies listed on the Stock Exchange period 2009-2012. The data used financial statements are the financial statements that have been published in the Indonesian Capital Market Directory (ICMD) in 2013 and in www.idx.co.id. The analysis tool used is multiple regression analysis, $t$ test, $F$ test and the coefficient of determination was tested with the classical assumption. Based on the analysis of data it can be concluded that the variable DER and CR have a significant effect on stock price.
\end{abstract}

Keywords: Financial statements, Fundamental factors, Stock price.

\section{Pendahuluan}

Pasar modal memiliki peranan penting dalam perkembangan dunia usaha, dimana peran dari pasar modal adalah sebagai lembaga perantara yang menghubungkan investor yang hendak menanamkan dananya pada perusahaan yang menjanjikan keuntungan dan perusahaan yang bisa memenuhi keinginan dari investor dalam memberikan keuntungan yang memadai melalui kinerja yang baik dan resiko yang kecil. Peranan pasar modal pada kegiatan perekonomian suatu negara adalah menjadi sumber pendanaan alternatif bagi suatu perusahaan sebagai sumber pembiayaan modern. Pasar modal dapat membentuk suatu simbiosis mutualisme antara investor dan perusahaan dalam suatu lingkungan pengalokasian dana secara efisien, dimana melalui pasar modal pihak-pihak yang memiliki kelebihan dana (investor) dapat memilih alternatif investasi yang memberikan return yang paling optimal dari perusahaan-perusahan yang terdaftar dalam suatu pasar modal. Pengetahuan yang memadai dan penilaian yang cermat dan analisis yang tepat dibutuhkan oleh investor dalam menginvestasikan dananya di pasar modal. Menurut Sunariyah (2006, h.32), perusahaan memiliki berbagai alternatif sumber pendanaan untuk menjalankan kegiatan operasional perusahaan yang dapat berasal dari dalam maupun dari luar perusahaan. Alternatif pendanaan dari dalam perusahaan dengan menggunakan laba yang ditahan perusahaan. Sedangkan alternatif pendanaan dari luar perusahaan dapat berasal dari kreditur berupa utang maupun pendanaan yang bersifat penyertaan dalam bentuk saham. Pendanaan melalui mekanisme penyertaan dilakukan dengan cara menjual saham perusahaan kepada masyarakat disebut penawaran umum atau dikenal dengan istilah go public.

Banyaknya perusahaan-perusahaan yang terdaftar di pasar modal membuat banyak para pemodal tertarik untuk menginvestasikan dananya dalam bentuk saham karena 
investasi dalam bentuk saham akan menjanjikan tingkat keuntungan yang lebih tinggi daripada menabungnya di bank, baik dari deviden maupun dari capital gain. Menurut Tjptono dan Hendy (2006, h.6), saham dapat didefinisikan sebagai tanda penyertaan atau kepemilikan seseorang atau badan dalam suatu perusahaan atau perseroan terbatas. Saham berwujud selembar kertas yang menerangkan bahwa pemilik kertas adalah pemilik perusahaan yang menerbitkan surat berharga tersebut. Menurut Fahmi (2012, h.86), dengan membeli dan memiliki saham investor akan memperoleh beberapa keuntungan sebagai bentuk kewajiban yang harus diterima yaitu memperoleh capital gain (selisih antara harga beli dan harga jual), memperoleh deviden (pembagian keuntungan yang diberikan perusahaan dan berasal dari keuntungan yang dihasilkan perusahaan), dan memiliki hak suara bagi pemegang saham biasa. Adanya keuntungan yang tinggi di dalam berinvestasi dalam bentuk saham dibarengi juga dengan resiko yang tinggi, salah satunya adalah adanya variasi harga saham yang ditawarkan oleh setiap perusahaan yang sahamnya dijualnya di pasar modal.

Investor di pasar modal sangat memperhatikan kemampuan perusahaan untuk menghasilkan, menunjang, dan meningkatkan profit perusahaan (Ulupui,2006). Investor sangat membutuhkan informasi yang disajikan dalam laporan keuangan perusahaan guna memprediksi harga saham di pasar modal, termasuk kondisi keuangan perusahaan di masa depan. Analisis untuk memprediksi harga saham dapat menggunakan analisis rasio keuangan berdasarkan informasi keuangan perusahaan. Informasi akuntansi dalam bentuk rasio keuangan memiliki kemampuan prediksi ketika diasosiasi dengan harga saham. Untuk dapat menginterpretasikan informasi akuntansi yang relevan dengan tujuan dan kepentingan pemakainya dikembangkan seperangkat teknik analisis yang didasarkan pada laporan keuangan yang dipublikasikan. Salah satu teknik tersebut yang populer diaplikasikan dalam praktek bisnis adalah analisis rasio keuangan. Hasil rasio keuangan merupakan alat yang digunakan untuk menilai kondisi dan kinerja keuangan perusahaan. Rasio keuangan yang berasal dari laporan keuangan ini sering disebut faktor fundamental perusahaan yang dilakukan dengan teknik analisis fundamental. Bagi perusahaanperusahaan yang go public diharuskan menyertakan rasio keuangan yang relevan sesuai dengan Keputusan Ketua Bapepam Nomor KEP-51/PM/1996 tanggal 17 Januari 1996 (BEJ).

Riset mengenai kegunaan informasi akuntansi (laporan keuangan) dalam hubungannya dengan harga saham di Bursa Efek Jakarta telah banyak dilakukan, antara lain sebagai berikut. Machfoedz (1994) menguji manfaat rasio keuangan dalam memprediksi perubahan laba perusahaan pada masa depan pada 89 perusahaan manufaktur yang terdaftar di BEJ dari tahun 1989-1993. Asyik (1999) menemukan bahwa rasio neraca dan laba rugi memiliki hubungan yang lebih kuat dengan return saham dibandingkan dengan rasio arus kas. Kennedy JSP, (2003), meneliti pengaruh ROA, ROE, earnings per share, profit margin, asset turnover, rasio leverage, dan debt to equity ratio terhadap return saham. Triyono dan Jogiyanto (2000) meneliti hubungan kandungan informasi arus kas, komponen arus kas, dan laba akuntansi dengan harga saham atau return saham.Tuasikal (2001) menguji manfaat informasi akuntansi dalam memprediksi return saham. Mirip dengan Tuasikal sebelumnya Parawiyati et al. (2000) meneliti penggunaan informasi keuangan untuk memprediksi keuntungan investasi bagi 
investor di pasar modal. Hasil pengujiannya menunjukkan bahwa variabel informasi keuangan tersebut berpengaruh signifikan sebagai prediktor laba dan arus kas untuk satu, dua, dan empat tahun ke depan. Selain itu, Natarsyah S. (2002) menganalisis pengaruh beberapa faktor fundamental dan risiko sistematik terhadap harga saham. Penelitiannya merupakan studi terhadap 16 industri barang konsumsi yang go public di pasar modal dalam periode 8 tahun (1990-1997) dengan mengasumsikan bahwa harga saham merupakan fungsi dari ROA, ROE, beta, book value, debt/equity dan required rate of return. Setelah melakukan pengujian terhadap hipotesis diperoleh hasil bahwa faktor fundamental seperti return on assets, dividend payout ratio, debt to equity ratio, book value equity pershare, dan indeks beta berpengaruh terhadap harga saham perusahaan. Uraian di atas menunjukkan bahwa hasil penelitian mengenai pengaruh rasio keuangan terhadap harga atau return saham masih sangat bervariatif. Melihat laba dan juga leverage masih menjadi perhatian yang penting bagi investor maka penelitian ini ingin menganalisis kembali temuan penelitian sebelumnya dari sudut fundamental perusahaan, yaitu rasio yang terdapat dalam laba (profitabilitas), terutama ROA, ROE, leverage, juga rasio likuiditas dan aktivitas terhadap tingkat imbal hasil (return) saham perusahaan-perusahaan yang masuk kategori industri barang konsumsi di BEJ.

Tujuan penelitian ini adalah untuk memberikan temuan empiris tentang pengaruh faktor-faktor fundamental perusahaan yaitu ROA,DER, TATO, dan CR terhadap harga saham pada perusahaan-perusahaan yang masuk kategori asuransi yang terdaftar di BEJ sejak tahun 2009-2012.

Berdasarkan pembahasan tersebut maka yang menjadi pokok permasalahan dalam penelitian ini yaitu:

1) Apakah variabel $R O A$ sebagai salah satu proksi faktor fundamental perusahaan berpengaruh terhadap harga saham pada perusahaan asuransi yang terdaftar di BEI 2009-2012?

2) Apakah variabel $D E R$ sebagai salah satu proksi faktor fundamental perusahaan berpengaruh terhadap harga saham pada perusahaan asuransi yang terdaftar di BEI 2009-2012?

3) Apakah TATO sebagai salah satu proksi faktor fundamental perusahaan berpengaruh terhadap harga saham pada perusahaan asuransi yang terdaftar di BEI 2009-2012?

4) Apakah variabel Current Ratio sebagai salah satu proksi faktor fundamental perusahaan berpengaruh terhadap harga saham pada perusahaan asuransi yang terdaftar di BEI 2009-2012?

5) Apakah variabel $R O A, D E R$, TATO, dan $C R$ secara bersama-sama berpengaruh terhadap harga saham pada perusahaan asuransi yang terdaftar di BEI 2009-2012?

\section{Definisi Operasional Variabel}

Untuk menjelaskan variabel-variabel yang sudah diklasifikasikan maka perlu definisi operasional untuk masing-masing variabel yang ada:

1. Rasio Likuiditas merupakan rasio untuk mengukur kemampuan perusahaan untuk menghasilkan keuntungan pada tingkat penjualan, asset, dan modal saham tertentu. Profitability dapat diukur beberapa hal yang berbeda, namun dalam dimensi yang saling terkait. Pertama, terdapat hubungan antara profit dengan sales sehingga terjadi 
residual return bagi perusahaan per rupiah penjualan. Pengukuran yang lainnya adalah return on investment (ROI) atau disebut juga return on asset (ROA), yang berkaitan dengan profit dan investasi atau aset yang digunakan untuk menghasilkannya. Variabel yang digunakan sebagai proksi rasio likuiditas yang juga merupakan salah satu faktor internal perusahaan adalah ROA. Return on asset (ROA) adalah kemampuan perusahaan memanfaatkan aktivanya untuk memperoleh laba. Ratio ini mengukur tingkat kembalian investasi yang dilakukan oleh perusahaan dengan menggunakan seluruh dana (aktiva) yang dimilikinya. return on asset (ROA) (Hanafi dan Halim,2003 : 84) dapat dirumuskan sebagai berikut:

$$
\text { ROA }=\frac{\text { LABA BERSIH }}{\text { TOTAL AKTIVA }} \times 100 \%
$$

2. Rasio Leverage adalah rasio yang mengukur seberapa jauh perusahaan menggunakan utang. Beberapa analis menggunakan istilah rasio solvabilitas, yang berarti kemampuan perusahaan memenuhi kewajiban keuangannya. Variabel yang digunakan sebagai proksi rasio leverage yang juga merupakan salah satu faktor internal perusahaan adalah DER.

$$
\text { DER }=\frac{\text { TOTAL HUTANG }}{\text { MODAL SENDIRI }}
$$

3. Rasio aktivitas menggambarkan hubungan antara tingkat operasi perusahaan (sales) dengan aset yang dibutuhkan untuk menunjang kegiatan operasi perusahaan tersebut. Rasio aktivitas juga dapat digunakan untuk memprediksi modal yang dibutuhkan perusahaan (baik untuk kegiatan operasi maupun jangka panjang). Misalnya untuk meningkatkan penjualan akan membutuhkan tambahan aset. Rasio aktivitas memungkinkan para analis menduga kebutuhan ini serta menilai kemampuan perusahaan untuk mendapatkan aset yang dibutuhkan untuk mempertahankan tingkat pertumbuhannya. Variabel yang digunakan sebagai proksi rasio aktivitasyang juga merupakan salah satu faktor fundamental perusahaan adalah total asset turn over (TATO).

$$
\text { TATO }=\frac{\text { PENJUALAN }}{\text { TOTAL AKTIVA }}
$$

4. Rasio modal kerja adalah rasio yang didasarkan atas klasifikasi aset dan liabilities dalam bentuk kategori lancar dan tidak lancar. Perbedaan secara tradisional antara current asset dan liabilities didasarkan pada jatuh tempo kurang dari satu tahun atau berdasarkan siklus operasi perusahaan yang normal (jika lebih). Variabel yang digunakan sebagai proksi rasio modal kerja yang juga merupakan salah satu faktor 
fundamental perusahaan adalah Current Ratio (CR).

$\mathrm{CR}=\frac{\text { AKTIVA LANCAR }}{\text { HUTANG LANCAR }}$

5. Menurut Sunariyah (2006, h.128), harga saham adalah harga suatu saham pada pasar yang sedang berlangsung di bursa efek. Harga saham dapat dipengaruhi oleh situasi pasar antara lain harga saham dipasar perdana ditentukan oleh penjamin emisi dan perusahaan yang akan go public (emiten), berdasarkan analisis fundamental perusahaan. Peranan penjamin emisi pada pasar perdana selain menentukan harga saham, juga melaksanakan penjualan saham kepada masyarakat sebagai calon pemodal. Sedangkan harga saham di pasar sekunder ditentukan oleh permintaan dan penawaran antara pembeli dan penjual.

\section{Metode Penelitian}

Populasi pada penelitian ini menggunakan perusahaan asuransi yang terdaftar di Bursa Efek Indonesia periode 2009-2012 yang berjumlah 10 perusahaan. Nama-nama perusahaan asuransi yang terdaftar di BEI adalah sebagai berikut:

\begin{tabular}{|c|c|c|}
\hline NO & NAMA EMITEN & KODE \\
SAHAM \\
\hline 1 & $\begin{array}{c}\text { ASURANSI BINA DANA ARTA } \\
\text { TBK }\end{array}$ & ABDA \\
\hline 2 & $\begin{array}{c}\text { ASURANSI HARTA AMAN } \\
\text { PRATAMA TBK }\end{array}$ & AHAP \\
\hline 3 & $\begin{array}{c}\text { ASURANSI MULTI ARHA GUNA } \\
\text { TBK }\end{array}$ & AMAG \\
\hline 4 & ASURANSI BINTANG TBK & ASBI \\
\hline 5 & ASURANSI DAYIN MITRA TBK & ASDM \\
\hline 6 & ASURANSI JAYA TANIA TBK & ASJT \\
\hline 7 & ASURANSI RAMAYANA TBK & ASRM \\
\hline 8 & $\begin{array}{c}\text { LIPPO GENERAL INSURANCE } \\
\text { TBK }\end{array}$ & LPGI \\
\hline 9 & $\begin{array}{c}\text { MASKAPAI REASURANSI } \\
\text { INDONESIA TBK }\end{array}$ & MREI \\
\hline 10 & PANIN INSURANCE TBK & PNIN \\
\hline \multicolumn{2}{|c}{} \\
\hline
\end{tabular}

Metode pengumpulan data yang digunakan pada penelitian ini merupakan metode observasi nonparticipant. Data yang digunakan berdasarkan sumbernya pada penelitian ini merupakan data sekunder. Data tersebut diperoleh melalui laporan ringkasan kinerja perusahaan tercatat (financial data and ratio) perusahaan asuransi yang tercatat pada Bursa Efek Indonesia periode 2009-2012, melalui situs www.idx.co.id. Alat analisis data 
yang digunakan uji asumsi klasik serta regresi linear berganda. Uji hipotesis menggunakan uji t dan uji F.

Hasil dan Pembahasan

\begin{tabular}{|c|c|c|c|c|c|c|}
\hline \multirow[b]{2}{*}{ NO } & \multirow[b]{2}{*}{ NAMA EMITEN } & \multirow[b]{2}{*}{ KODE SAHAM } & \multicolumn{4}{|c|}{$\operatorname{ROA}(\mathrm{X})$} \\
\hline & & & 2009 & 2010 & 2011 & 201 \\
\hline 1 & ASURANSI BINA DANA ARTA TBK & ABDA & (5.03) & 5.36 & 7.92 & 6.61 \\
\hline 2 & ASURANSI HARTA AMAN PRATAMA TBK & AHAP & $(7.22)$ & 7.44 & 9.95 & 6.56 \\
\hline 3 & ASURANSI MULTI ARHA GUNA TBK & AMAG & 9.72 & 9.07 & 9.08 & 10.90 \\
\hline 4 & ASURANSI BINTANG TBK & ASBI & (195) & 110 & 3.71 & 7.11 \\
\hline 5 & ASURANSI DAYIN MITRA TBK & ASDM & (2.93) & 4.59 & 6.58 & 2.87 \\
\hline 6 & ASURANSI JAYA TANIA TBK & ASJT & (5.16) & 6.58 & 7.50 & 6.59 \\
\hline 8 & ASURANSI RAMAYANA TBK & ASRM & $(6.06)$ & 5.33 & 6.10 & 3.05 \\
\hline 9 & LIPPO GENERAL INSURANCE TBK & LPGI & (3.75) & 6.1 & 4.70 & 2.28 \\
\hline 10 & MASKAPAI REASURANSI INDONESIA TBK & MREI & (9.39) & 10.34 & 10.96 & 2.40 \\
\hline 11 & PANIN INSURANCE TBK & PNIN & (7.40) & 9.41 & 9.28 & (6.44) \\
\hline
\end{tabular}

\begin{tabular}{|c|c|c|c|c|c|c|}
\hline \multirow[b]{2}{*}{ NO } & \multirow[b]{2}{*}{ NAMA EMITEN } & \multirow[b]{2}{*}{ KODE SAHAM } & \multicolumn{4}{|c|}{ DER $(X)$} \\
\hline & & & 2009 & 2010 & 2011 & 2012 \\
\hline 1 & ASURANSI BINA DANA ARTA TBK & ABDA & 3.18 & 3.28 & 173 & 189 \\
\hline 2 & ASURANSI HARTA AMAN PRATAMA TBK & AHAP & 0.91 & 116 & 106 & 2.05 \\
\hline 3 & ASURANSI MULTI ARHA GUNA TBK & AMAG & 0.86 & 0.86 & 0.65 & 0.76 \\
\hline 4 & ASURANSI BINTANG TBK & ASBI & 114 & 1.66 & 140 & 2.10 \\
\hline 5 & ASURANSI DAYIN MITRA TBK & ASDM & 133 & 1.38 & 126 & 4.68 \\
\hline 6 & ASURANSI JAYA TANIA TBK & ASJT & 0.78 & 0.73 & 1.03 & 1.18 \\
\hline 8 & ASURANSI RAMAYANA TBK & ASRM & 187 & 2.23 & 2.61 & 5.67 \\
\hline 9 & LIPPO GENERAL INSURANCE TBK & LPGI & 0.27 & 0.27 & 0.36 & 0.45 \\
\hline 10 & MASKAPAI REASURANSI INDONESIA TBK & MREI & 1.37 & 144 & 140 & 1.42 \\
\hline 11 & PANIN INSURANCE TBK & PNIN & 0.80 & 0.72 & 0.44 & 0.40 \\
\hline
\end{tabular}

\begin{tabular}{|c|c|c|c|c|c|c|}
\hline \multirow[b]{2}{*}{ NO } & \multirow[b]{2}{*}{ NAMA EMITEN } & \multirow[b]{2}{*}{ KODE SAHAM } & \multicolumn{4}{|c|}{ TATO $(x)$} \\
\hline & & & 2009 & 2010 & 2011 & 2012 \\
\hline 1 & ASURANSI BINA DANA ARTA TBK & ABDA & 0.65 & 0.50 & 0.49 & 0.36 \\
\hline 2 & ASURANSI HARTA AMAN PRATAMA TBK & AHAP & 0.79 & 0.92 & 101 & 0.72 \\
\hline 3 & ASURANSI MULTI ARHA GUNA TBK & AMAG & 0.43 & 0.38 & 0.30 & 0.27 \\
\hline 4 & ASURANSI BINTANG TBK & ASBI & 0.32 & 0.30 & 0.38 & 0.37 \\
\hline 5 & ASURANSI DAYIN MITRA TBK & ASDM & 0.37 & 0.34 & 0.35 & 0.12 \\
\hline 6 & ASURANSI JAYA TANIA TBK & ASJT & 0.51 & 0.60 & 0.70 & 0.93 \\
\hline 8 & ASURANSI RAMAYANA TBK & ASRM & 0.64 & 0.52 & 0.46 & 0.33 \\
\hline 9 & LIPPO GENERAL INSURANCE TBK & LPGI & 0.28 & 0.26 & 0.34 & 0.31 \\
\hline 10 & MASKAPAI REASURANSI INDONESIA TBK & MREI & 0.90 & 0.86 & 0.82 & 0.64 \\
\hline 11 & PANIN INSURANCE TBK & PNIN & 0.11 & 0.16 & 0.22 & 0.18 \\
\hline
\end{tabular}

\begin{tabular}{|c|c|c|c|c|c|c|}
\hline \multirow{2}{*}{ NO } & \multirow{2}{*}{ NAMA EMITEN } & \multirow{2}{*}{ KODE SAHAM } & \multicolumn{4}{|c|}{$\mathrm{CR}(\mathrm{X})$} \\
\hline & & & 2009 & 2010 & 2011 & 2012 \\
\hline 1 & ASURANSI BINA DANA ARTA TBK & ABDA & 1.23 & 126 & 150 & 1.47 \\
\hline 2 & ASURANSI HARTA AMAN PRATAMA TBK & AHAP & 199 & 178 & 184 & 1.44 \\
\hline 3 & ASURANSI MULTI ARHA GUNA TBK & AMAG & 2.10 & 2.2 & 2.51 & 2.20 \\
\hline 4 & ASURANSI BINTANG TBK & $\mathrm{ASBI}$ & 160 & 142 & 154 & 1.39 \\
\hline 5 & ASURANSI DAYIN MITRA TBK & ASDM & 1.67 & 166 & 172 & 1.20 \\
\hline 6 & ASURANSI JAYA TANIA TBK & ASJT & 2.24 & 2.36 & 178 & 1.71 \\
\hline 8 & ASURANSI RAMAYANA TBK & ASRM & 141 & 1.36 & 132 & 1.12 \\
\hline 9 & LIPPO GENERAL INSURANCE TBK & LPGI & 4.57 & 4.61 & 3.67 & 6.02 \\
\hline 10 & MASKAPAI REASURANSI INDONESIA TBK & MREI & 1.64 & 162 & 166 & 1.66 \\
\hline
\end{tabular}




\begin{tabular}{|c|c|c|c|c|}
\hline \multirow[b]{2}{*}{ KODE SAHAM } & \multicolumn{4}{|c|}{ HRGSAHAM (Y) } \\
\hline & 2009 & 2010 & 2011 & 201 \\
\hline ABDA & 217.00 & 376.00 & 770.00 & $1,830.00$ \\
\hline AHAP & 144.00 & 25.00 & 200.00 & 190.00 \\
\hline AMAG & 95.00 & 144.00 & 147.00 & 230.00 \\
\hline ASBI & 290.00 & 255.00 & 275.00 & 490.00 \\
\hline ASDM & 180.00 & 600.00 & 500.00 & 740.00 \\
\hline ASJT & 420.00 & 420.00 & 420.00 & 460.00 \\
\hline ASRM & 990.00 & $1,040.00$ & 820.00 & 980.00 \\
\hline LPGI & 570.00 & $1,160.00$ & $1,690.00$ & $1,990.00$ \\
\hline MREI & 285.00 & 550.00 & 760.00 & 1710.00 \\
\hline PNIN & 255.00 & 570.00 & 415.00 & 520.00 \\
\hline
\end{tabular}

Berdasarkan Uji T dengan menggunakan SPSS didapat hasil sebagai berikut:

\begin{tabular}{|c|c|c|c|c|c|c|}
\hline \multicolumn{7}{|c|}{ Coefficientsa } \\
\hline \multirow[b]{2}{*}{ Model } & & \multicolumn{2}{|c|}{$\begin{array}{l}\text { Unstandardized } \\
\text { Coefficients }\end{array}$} & \multirow{2}{*}{$\begin{array}{c}\begin{array}{c}\text { Standardiz } \\
\text { ed } \\
\text { Coefficient } \\
\text { s }\end{array} \\
\text { Beta }\end{array}$} & \multirow[b]{2}{*}{$\mathrm{t}$} & \multirow[b]{2}{*}{ Sig. } \\
\hline & & B & Std. Error & & & \\
\hline \multirow[t]{5}{*}{1} & (Constant) & -523.648 & 410.186 & & -1.277 & .210 \\
\hline & ROA & 17.952 & 11.713 & .222 & 1.533 & .134 \\
\hline & DER & 214.450 & 83.449 & .490 & 2.570 & .015 \\
\hline & TATO & 144.336 & 332.972 & .071 & .433 & .667 \\
\hline & CR & 310.361 & 94.537 & .683 & 3.283 & .002 \\
\hline
\end{tabular}

Dependent Variable: harga saham

Dari data yang ada diketahui persamaan yang terbentuk adalah sebagai berikut:

$Y=-523,648+17,952 \times 1+214,450 \times 2+144,336 \times 3+310,361 \times 4$

Dimana:

Y adalah Harga Saham

$\mathrm{X} 1$ adalah ROA

$\mathrm{X} 2$ adalah DER

X3 adalah TATO

$\mathrm{X} 4$ adalah $\mathrm{CR}$

Dari data ini dapat pula dijelaskan hal-hal sebagai berikut:

1. Konstanta 523,648 menunjukkan bahwa apabila Variable ROA,DER,TATO, dan $\mathrm{CR}$ adalah konstan maka nilai harga saham adalah negatif.

2. Koefisien ROA sebesar 17,952 berarti koefisien Return Of Asset (ROA) memiliki pengaruh searah terhadap Harga Saham yaitu ROA naik maka Harga Saham juga 
naik. Signifikasi ROA adalah $0,134(>0,05)$ maka ROA tidak berpengaruh secara signifikan terhadap Harga Saham.

3. Koefisien DER sebesar 214,450 berarti koefisien Debt Equity Ratio (DER) memiliki pengaruh searah terhadap Harga Saham yaitu DER naik maka Harga Saham juga naik. Signifikasi DER adalah 0,015(<0,05) maka DER berpengaruh signifikan terhadap Harga Saham.

4. Koefisien TATO sebesar 144,337 berarti koefisien Total Asset Turn Over (TATO) memiliki pengaruh searah terhadap Harga Saham yaitu TATO naik maka Harga Saham juga naik. Signifikasi TATO adalah 0,667(>0,05) maka TATO tidak berpengaruh secara signifikan terhadap Harga Saham.

5. Koefisien CR adalah sebesar 310,361 berarti Current Ratio (CR) memiliki pengaruh searah terhadap Harga Saham yaitu CR naik maka Harga Saham juga naik. Signifikasi CR adalah $0,02(<0,05)$ maka CR berpengaruh secara signifikan terhadap Harga Saham.

Dari output SPSS didapati hasil R2 sebagai berikut:

\begin{tabular}{|l|r|r|r|r|}
\hline \multicolumn{7}{|c|}{ Model Summaryb } \\
\hline Model & $\mathrm{R}$ & R Square & $\begin{array}{c}\text { Adjusted } \\
\text { R Square }\end{array}$ & $\begin{array}{c}\text { Std. Error } \\
\text { of the } \\
\text { Estimate }\end{array}$ \\
\hline 1 & .533 & .284 & .202 & 440.44958 \\
\hline
\end{tabular}

Dari data ini diketahui pada ROA, DER, TATO, CR secara bersama-sama dapat menerangkan variabel perubahan laba sebesar 28,4\% berarti lemah untuk menjelaskan variabel dependen yaitu Harga Saham.

\begin{tabular}{|c|c|c|c|c|c|c|}
\hline \multicolumn{7}{|c|}{ ANOVA ${ }^{b}$} \\
\hline Model & & $\begin{array}{c}\text { Sum of } \\
\text { Squares }\end{array}$ & df & Mean Square & $\mathrm{F}$ & Sig. \\
\hline \multirow[t]{3}{*}{1} & Regression & 2691555.667 & 4 & 672888.917 & 3.469 & $.017^{a}$ \\
\hline & Residual & 6789854.108 & 35 & 193995.832 & & \\
\hline & Total & 9481409.775 & 39 & & & \\
\hline
\end{tabular}

a. Predictors: (Constant), CR, ROA, TATO, DER

b. Dependent variable: HRG SAHAM

Dari data Anova diketahui bahwa berdasrkan uji $\mathrm{F}$ didapat nilai sebesar 3,469 dengan signifikasi $0,017(<0,05)$ berarti variabel-variabel independen (ROA,DER, TATO,CR) mempengaruhi secara bersama-sama secara simulatan terhadap variabel dependen(Harga Saham). Hal ini juga menunjukkan bahwa variabel-variabel independen sudah tepat dalam mengukur variabel dependentnya sehingga model regresi sudah fit.

Pengujian Asumsi Klasik.

Model yang digunakan dalam penelitian ini adalah regresi linier berganda. Agar hasil regresi sahih maka harus terpenuhi asumsi klasik, yaitu Normalitas, autokorelasi, 
multikolinieritas, dan heteroskedastisitas.

\section{(1) Uji Normalitas.}

Hasil analisis terhadap asumsi normalitas ini dikatakan baik apabila semua data tersebar secara merata di sekitar garis horisontal mengikuti garis horisontal. Untuk penelitian ini didapatkan hasil sebagai berikut:

Normal P.P Plot of Regression Standardized Residual

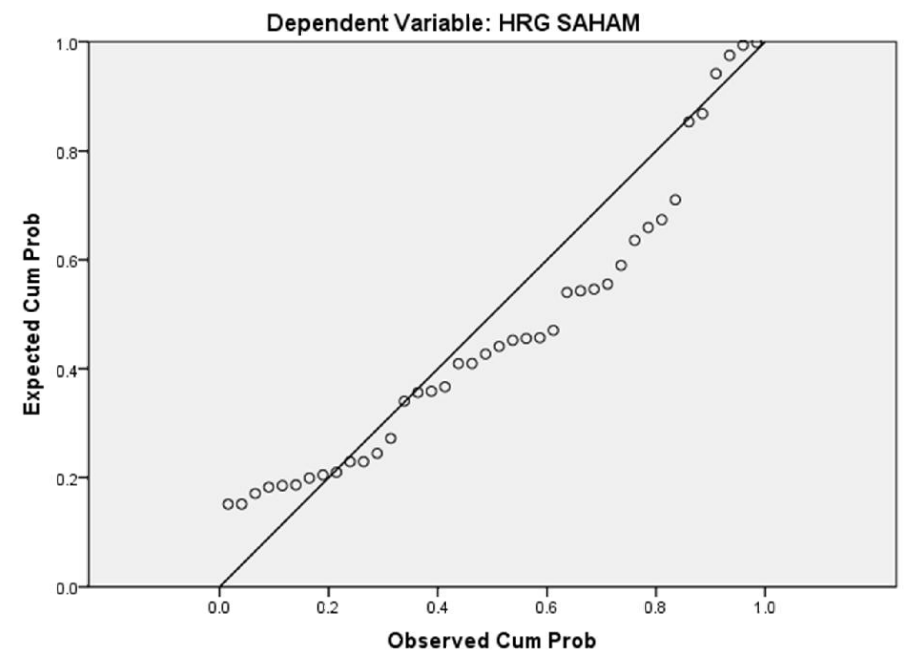

Berdasarkan gambar yang ada diketahui data tersebar merata di sekitar garis horisontal dan mengikuti garis horisontal (memenuhi uji Normalitas).

(2) Uji Multikolinieritas.

Multikolinieritas terindikasi apabila terdapat hubungan linier di antara variabel independen yang digunakan dalam model. Metode untuk menguji adanya multikolinieritas adalah bahwa nilai VIF variabel independent dibawah nilai 10 dan tolerance value diatas 0,10 sehingga dapat disimpulkan tidak terjadi multikolinieritas dalam model regresi. Hasil yang diperoleh dari Uji Multikolinieritas dengan menggunakan SPSS dapat dilihat dari tabel berikut ini:

\begin{tabular}{|c|c|c|c|c|}
\hline \multicolumn{5}{|c|}{ Coefficientsa } \\
\hline \multirow[b]{2}{*}{ Model } & & \multicolumn{2}{|c|}{ Collinearity Statistics } & \multirow{2}{*}{ Kesimpulan } \\
\hline & & Tolerance & VIF & \\
\hline \multirow[t]{5}{*}{1} & (Constant) & & & \\
\hline & ROA & .978 & 1.023 & Bebas Multikolineritas \\
\hline & DER & .562 & 1.779 & Bebas Multikolineritas \\
\hline & TATO & .757 & 1.320 & Bebas Multikolineritas \\
\hline & CR & .473 & 2.116 & Bebas Multikolineritas \\
\hline
\end{tabular}

Dependent Variable: harga saham

(3) Uji Heteroskedastisitas.

Uji Heteroskedastisitas bertujuan untuk menguji apakah dalam model regresi 
terjadi ketidaksamaan varians dari residual dari satu pengamatan ke pengamatan yang lain. Pengujian ini digunakan untuk melihat apakah variabel penganggu mempunyai varian yang sama atau tidak. Heteroskedastisitas mempunyai suatu keadaan bahwa varian dari residual suatu pengamatan ke pengamatan yang lain berbeda. Salah satu metode yang digunakan untuk menguji ada tidaknya Heterokedastisitas akan mengakibatkan penafsiran koefisien-koefisien regresi menjadi tidak efisien. Hasil dari penafsiaran akan menjadi kurang dari semestinya. Heterokedastisitas bertentangan dengan salah satu asumsi dasar regresi linear, yaitu bahwa variasi residual sama untuk semua pengamatan atau disebut Homokedastisitas (Gujarati dalam Elmasari, 2010:53). Untuk mendeteksi ada tidaknya heterokedastisitas yaitu dengan melihat grafik plot antara nilai prediksi variabel terikat (dependent) yaitu ZPRED dengan residualnya SRESID. Deteksi ada atau tidaknya Heterokedastisitas adalah dengan melihat ada tidaknya pola tertentu pada grafik scaterrplot antara SRESID dan ZPRED dimana Sumbu Y adalah $\mathrm{Y}$ yang telah diprediksi, dan sumbu $\mathrm{X}$ adalah residual (Yprediksi- $\mathrm{Y}$ sesungguhnya) yang telah distudentized. Dasar analisisnya adalah sebagai berikut:

a. Jika ada pola tertentu, seperti titik-titik yang ada membentuk pola tertentu yang teratur (bergelombang, melebar, kemudian menyempit), maka mengindikasikan telah terjadi Heterokedastisitas.

b. Jika ada pola yang jelas serta titik-titik menyebar diatas dan dibawah angka 0 pada sumbu Y, maka tidak terjadi Heterokedastisitas. Berdasarkan hasil pengujian Heterokedastisitas yang perhitungannya dengan menggunakan SPSS didapat hasil sebagai berikut:
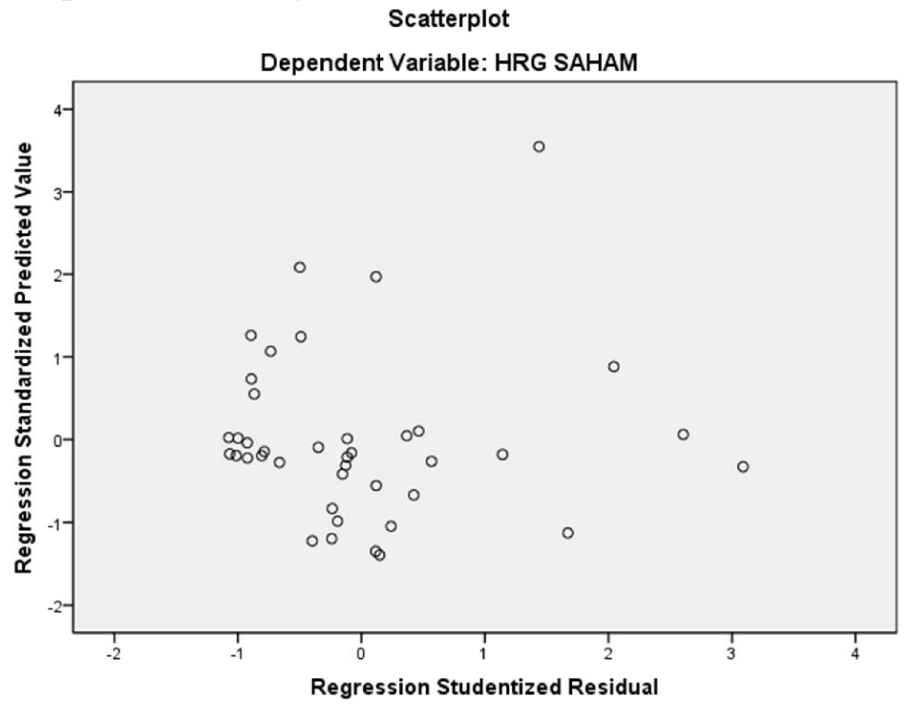

Dari gambar di atas terlihat data tersebar dengan tidak beraturan diantara sumbu Y baik diatas nilai 0 maupun dibawah nilai 0 , maka dikatakan tidak terjadi heteroskedastisitas terhadap data yang ada (uji heterokedastisitas terpenuhi). Uji autokorelasi merupakan pengujian asumsi dalam regresi dimana variabel dependen tidak berkorelasi dengan dirinya sendiri. Maksud korelasi dengan diri sendiri adalah bahwa nilai dari variabel dependen tidak 
berhubungan dengan nilai variabel itu sendiri, baik nilai variabel sebelumnya maupun nilai periode sesudahnya (Santosa \& Ashari, 2009:240).

Dasar untuk menunjukkan ada tidaknya autokorelasi adalah sebagai berikut:

\begin{tabular}{|c|c|c|}
\hline HIPOTESIS & KEPUTUSAN & JIKA \\
\hline Tidak ada autokorelasi positif & TOLAK & $0<\mathrm{d}<\mathrm{dl}$ \\
\hline Tidak ada autokorelasi positif & NO DECISION & $\mathrm{dl} \leq \mathrm{d} \leq \mathrm{du}$ \\
\hline Tidak ada autokorelasi negatif & TIDAK & $4-\mathrm{dl} \leq \mathrm{d} \leq 4$ \\
\hline Tidak ada autokorelasi negatif & NO DECISION & $4-\mathrm{du} \leq \mathrm{d} \leq 4-\mathrm{dl}$ \\
\hline Tidak ada autokorelasi positif maupun negatif & TIDAK DITOLAK & $\mathrm{d} u<\mathrm{d}<4-\mathrm{du}$ \\
\hline
\end{tabular}

(Sumber: Imam Gozali,2009,Analisis Mutlivariate dengan SPSS, Hal 100)

\begin{tabular}{|c|c|c|c|c|c|c|c|}
\hline Model & $\begin{array}{c}\text { Durbin- } \\
\text { Watson }\end{array}$ & $d l$ & $d u$ & $4-d l$ & $4-d u$ & Hasil & Keterangan \\
\hline Regresi & 1.961 & 1.2848 & 1.7209 & 2.7152 & 2.2791 & $1.7209<1.961<2.2791$ & $\begin{array}{c}\text { Tidak Ada } \\
\text { Autokorelasi Positif } \\
\text { Maupun Negatif }\end{array}$ \\
\hline
\end{tabular}

Berdasarkan hasil uji asumsi klasik (normalitas, autokorelasi, multikolinieritas, Heteroskedastisitas) diperoleh hasil analisis bahwa dalam model yang digunakan sudah tidak terjadi penyimpangan asumsi klasik, artinya model regresi pada penelitian dapat digunakan sebagai dasar analisis.

\section{Kesimpulan}

Berdasarkan hasil penelitian dan pembahasan yang telah dilakukan, diperoleh kesimpulan sebagai berikut:

1.Hasil uji t menunjukkan bahwa ROA, DER, TATO, CR berpengaruh positif terhadap Harga Saham. Variabel DER dan CR berpengaruh secara signifikan terhadap Harga Saham.

2.Hasil dari uji asumsi klasik (normalitas, autokorelasi, multikolinieritas, heterokedastisitas) diperoleh hasil analisis bahwa dalam model yang digunakan sudah tidak terjadi penyimpangan asumsi klasik, artinya model regresi pada penelitian dapat digunakan sebagai dasar analisis.

3.Penelitian ini mempunyai keterbatas dengan variabel yang digunakan yaitu hanya 4 variabel independent (ROA,DER, TATO,CR) dan 1 variabel Dependent (Harga Saham). Penelitian ini juga mempunyai keterbatasan dalam populasi yang digunakan yaitu hanya pada perusahaan yang masuk kategori Asuransi untuk data 2009-2012 yang ada di BEI.

\section{Saran}

Berdasarkan hasil penelitian dan pembahasan yang telah dilakukan diperoleh kesimpulan sebagai berikut:

1.Penelitian selanjutnya dapat melakukan penelitian dengan menggunakan jangka waktu pengamatan yang lebih lama. 
2.Penelitian selanjutnya disarankan untuk melakukan penelitian dengan populasi pada jenis industri yang berbeda selain Jenis Asuransi sehingga dapat dibandingkan pengaruh faktor-faktor fundamental tersebut terhadap harga saham.

3.Pengaruh keempat variabel masih kecil terhadap harga saham, oleh karena itu bagi peneliti yang akan meneliti dengan tema yang sama, sebaiknya jumlah variabel independen, agar hasil penelitian bisa lebih baik lagi.

\section{Daftar Pustaka}

Brigham, Eugene F. dan Joel F. Houston 2009, Dasar - Dasar Manajemen Keuangan, Buku 1, Edisi 10, Salemba Empat, Jakarta, hal 33-36.

Darmadji, Tjiptono dan Hendy M.Fakhruddin 2006, Pasar Modal di Indonesia, Salemba Empat, Jakarta, hal 165-202

Djarwanto 1996, Mengenal Beberapa Uji Statistik dalam Penelitian, Yogyakarta, Liberty, hal 134-164. Fadjrith,Asyik Nur dan Soelistyo,2000. Kemampuan Rasio Keuangan dalam memprediksi laba, penetapan rasio keuangan sebagai discriminator, Jurnal Ekonomi dan Bisnis Indonesia. Vol 15, No.3: Juli 2000, hal 313-331.

Fahmi, Irham 2012, Pengantar Pasar Modal, edisi 1, Alfabeta, Bandung, hal 125-137.

Hasan, Iqbal 2001, Pokok-pokok Materi Stastistik 2, edisi 2, Bumi Aksara, Jakarta.

Helfert, 1991, Analisis laporan keuangan ( terjemahan Herman Wibowo). Edisi 7, Jakarta. Penerbit Erlangga, hal 7-13.

Husnan, Suad 2009, Dasar-dasar Teori Portofolio dan Analisis Sekuritas, Edisi 4, UPP STIM YKPN, Yogyakarta, hal 150-168.

Ghozali, Imam, 2009,Aplikasi Analisis Multivariate dengan program SPSS, Semarang, Badan Penerbit Universitas Diponegoro, hal 45-53.

Indonesian Capital Market Directory (ICMD) tahun 2013, www.idx.co.id.

Kasmir 2010, Analisa Laporan Keuangan, Rajawali Pers, Jakarta, hal 11-21.

Krisnawati Br. Tarigan, Nurainun Bangun, dan Joanita 2007, Analisis Pengaruh ROE dan EPS Terhadap Harga Saham Perusahaan Manufaktur Yang Terdaftar Di Bursa Efek Jakarta, Jurnal Akuntansi, Volume 7, Nomor 2, hal 173-194.

Munawir, 2000. Analisis laporan keuangan, Yogyakarta, Liberty, hal 64-76.

Rd. Neneng Rina Andriani dan Aryati Kusumastuti 2008, Pengaruh Earning Per Share Terhadap Harga Pasar Saham, Jurnal Akuntansi FE Unsil, Volume 3, Nomor 2., hal 6787.

Sunariyah 2006, Pengetahuan Pasar Modal, edisi 5, UPP STIM YKPN, Yogyakarta, hal 4-12.

Tandelilin, Eduardus 2010, Portofolio dan Investasi Teori dan Aplikasi, edisi 1, Kanisius, Yogyakarta, hal 342-343.

Trihendradi, Cornelius 2008, Analisis Data Statistik SPSS 16, Andi, Yogyakarta, hal 110-115 